\title{
Effect of different concentrations of amino acids in human serum and follicular fluid on the development of one-cell mouse embryos in vitro
}

\author{
T. Nakazawa ${ }^{1 *}$, K. Ohashi ${ }^{2}$, M. Yamada ${ }^{1}$, S. Shinoda ${ }^{1}$, F. Saji ${ }^{2}$, \\ Y. Murata ${ }^{2}$ and H. Araki ${ }^{1}$ \\ ${ }^{1}$ Research and Development Center, Fuso Pharmaceutical Industries Ltd, 2-3-30, Morinomiya, Joto-ku, \\ Osaka 536, Japan; and ${ }^{2}$ Department of Obstetrics and Gynecology, Osaka University Medical School, \\ 2-2 Yamada-oka, Suita, Osaka 565, Japan
}

\begin{abstract}
As a model for establishing an optimized medium for human in vitro fertilization (IVF), modified human tubal fluid (HTF) media containing amino acids at concentrations found in human serum and follicular fluid were prepared, and the effect of the media on development of random-bred (ICR) and $F_{1}$ hybrid (CBFI) mice embryos was studied. The total concentrations of amino acids found in serum and follicular fluid were about one-third to one-half the concentrations present in two conventional media used in human IVF: Ham's F-10 and Eagle's minimal essential medium (MEM). When ICR mouse embryos were cultured in the HTF medium containing 21 amino acids at concentrations found in follicular fluid, the number of embryos developing to morulae at $72 \mathrm{~h}$ and to blastocysts at $96 \mathrm{~h}$ increased in comparison with those cultured in HTF medium. When HTF containing amino acids at concentrations found in serum was used, only induced morula formation at $72 \mathrm{~h}$ was enhanced. The number of hatching blastocysts at $96 \mathrm{~h}$ also increased when CBFI mouse embryos were cultured with HTF supplemented with amino acids at concentrations found in follicular fluid. When ICR mouse embryos were cultured in modified HTF media containing concentrations of amino acids found in Ham's F-10 and MEM that contained higher concentrations of glutamine, embryo development was inhibited. The amount of ammonium produced during incubation for 3 days was significantly less when embryos were cultured in media containing concentrations of amino acids found in follicular fluid compared with when Ham's F-10 or MEM was the culture medium. Ammonium is produced by the breakdown of glutamine in the culture medium during incubation with or without embryos. These results suggest that the concentrations of amino acids found in follicular fluid are more effective and safer for embryo culture than those in other media currently in use.
\end{abstract}

\section{Introduction}

The addition of serum to culture medium, conditioned medium and somatic cell co-culture systems supports the development in vitro of embryos from various mammalian species (Eyestone and First, 1989; Myers et al., 1994; Rorie et al., 1994). However, these culture systems are not favoured for human in vitro fertilization (IVF) because of their potential contamination with undesirable components such as viruses. To avoid viral infection, it is important to prepare a serum-free medium that provides optimal conditions for embryo development. In conventional human IVF, embryos are cultured in commercially available media such as Ham's F-10, Eagle's MEM and $\alpha$-MEM, which have been developed for somatic cell culture. These culture media contain components, such as amino acids, vitamins and energy substrates, to enhance the growth of somatic

${ }^{*}$ Correspondence

Received 4 June 1997 cells. However, it is not known whether these components are required for embryo development.

When mammalian embryos are cultured in medium containing amino acids, the embryonic cells take up amino acids (Brinster, 1971; Epstein and Smith, 1973; Kaye et al., 1982), and the presence of amino acids enhances embryo development (Kane and Foote, 1970; Kane et al., 1986; Miyoshi et al., 1995). One reason for the requirement for amino acids is that they are substrates for protein synthesis, which occurs to a considerable extent in early embryos (Morgan and Kane, 1993; Lamb and Leese, 1994). However, ammonium produced by embryo metabolism and by the spontaneous breakdown of amino acids in the culture medium inhibits embryo development (Gardner and Lane, 1993). This findings suggests that media for IVF should not contain amino acids at concentrations higher than those needed for embryo development.

In the present study, the effects of supplementation of human tubal fluid (HTF; Quinn ef al., 1985) medium with amino acids on the development of mouse embryos in vitro were 
analysed. Human follicular fluid and serum, as well as two conventional media, Ham's F-10 (Ham, 1963) and Eagle's minimal essential medium (MEM) (Eagle, 1959) which are frequently used as culture media for IVF, were used as amino acid sources. Random-bred ICR and $\mathrm{F}_{\mathrm{I}}$ hybrid CBF1 strains of mice were used. In random-bred mice, embryo development is depressed at the two-cell stage in traditional culture, while $\mathrm{F}_{1}$ hybrid mouse embryos progress through this block (Dandekar and Glass, 1987). Embryos were cultured in the modified HTF media and embryo development was observed as a function of the concentrations of free amino acids and the production of ammonium.

\section{Materials and Methods}

\section{Collection of human follicular fluid and serum}

Human follicular fluid and serum were collected from 21 women enrolled in the IVF program at Osaka University Hospital. Informed consent was obtained. Patients received human menopausal gonadotrophin and buserelin acetate. Follicular growth was monitored by ultrasonography. When the leading follicle reached $18 \mathrm{~mm}$ in diameter, 10000 iu human chorionic gonadotrophin ( $\mathrm{hCG}$ ) was administered. Oocytes were recovered transvaginally $36 \mathrm{~h}$ after the hCG injection. Venous blood was collected before oocyte recovery. Follicular fluid and blood were centrifuged at $400 \mathrm{~g}$ for $10 \mathrm{~min}$ at $4^{\circ} \mathrm{C}$, and the supernatants were stored below $-20^{\circ} \mathrm{C}$. Individual fluid samples were kept separately until use.

\section{Measurement of free amino acids}

Twenty-one samples of follicular fluid and serum were deproteinized by the addition of an equal volume of $5 \%(\mathrm{w} / \mathrm{v})$ sulfosalicylic acid solution and then centrifuged at $1500 \mathrm{~g}$ for $10 \mathrm{~min}$ at $4^{\circ} \mathrm{C}$. The individual concentrations of 21 free amino acids were measured with an amino acid analyser (Hitachi L-2500, Tokyo).

\section{Preparation of culture media}

HTF medium containing no amino acids was used as basic medium, and all culture media containing amino acids were prepared by the addition of amino acids to this medium. Four media were prepared containing amino acids at concentrations found in follicular fluid, serum, Ham's F-10 medium and MEM. All media were supplemented with $0.5 \%(\mathrm{w} / \mathrm{v}) \mathrm{BSA}$ (Sigma, St Louis, MO) and were passed through a 0.22 micrometer filter (Mirex GV, Millipore, Bedford, MA).

\section{Collection and culture of mouse embryos}

Random-bred ICR and $\mathrm{F}_{1}$ hybrid CBFI mice (obtained from Japan Clea, Tokyo, and Japan SLC, Shizuoka, respectively) were given an i.p. injection of 5 iu pregnant mares serum gonadotrophin (PMSG, Teikoku Zoki, Tokyo) followed by 5 iu hCG (Teikoku Zoki) $48 \mathrm{~h}$ after PMSG injection. Female mice were mated with male mice of the same strain and killed $18 \mathrm{~h}$ after the hCG injection to recover one-cell embryos from the oviducts. The embryos were treated with $0.1 \%(\mathrm{w} / \mathrm{v})$ hyaluronidase (Sigma) in HTF medium containing $0.5 \%(\mathrm{w} / \mathrm{v}) \mathrm{BSA}$ (HTF/0.5\%BSA) to remove cumulus cells, and then rinsed with HTF $/ 0.5 \%$ BSA. Embryos from 5-7 females were pooled and placed randomly in groups of 10-20 into $100 \mu \mathrm{l}$ droplets of a pre-equilibrated test medium on a $65 \mathrm{~mm}$ diameter Petri dish, and incubated for $72 \mathrm{~h}$ and $96 \mathrm{~h}$ under $5 \% \mathrm{CO}_{2}$ in air at $37^{\circ} \mathrm{C}$.

Embryo development was observed with a phase-contrast microscope after incubation period.

\section{Determination of ammonium and free amino acids during incubation}

Each medium was pre-equilibrated overnight in $100 \mu \mathrm{l}$ droplets under a layer of paraffin oil and then incubated with and without ten ICR embryos for 3 days at $37^{\circ} \mathrm{C}$ in $5 \% \mathrm{CO}_{2}$ in air. Aliquots $(50 \mu \mathrm{l})$ of each medium were processed for determination of ammonium after 0,24 and $72 \mathrm{~h}$ of incubation. Determination of ammonium was performed by enzymatic analysis (Ammoniak, Boehringer Mannheim, Mannheim). The remaining $30 \mu \mathrm{l}$ of each sample was processed simultaneously for determination of free amino acids as described above.

\section{Statistical analyses}

The results of the determination of free amino acids were analysed by the non-paired Student's $t$ test. The percentage of embryos developed to various stages was calculated for each experimental group, and the data were analysed by a one-way analysis of variance (ANOVA). When the ANOVA test showed significant differences $(P<0.05)$, differences between individual treatments were assessed by the multiple comparisons test according to Tukey $(P<0.05)$.

\section{Results}

The concentrations of free amino acids in human follicular fluid, serum, Ham's F-10 and MEM media are listed (Table 1). Eleven amino acids were present at significantly higher concentrations in serum than in follicular fluid. Ham's F-10 contains all amino acids except taurine, whereas MEM lacks nine amino acids. These conventional media contained over 5-11 times the concentration of glutamine found in serum and follicular fluid. The total concentration of amino acids was also higher ( 1.5 to 3.1 times) in conventional media than in serum and follicular fluid.

One-cell embryos were cultured in HTF medium and two modified HTF media containing amino acids at concentrations found in follicular fluid (HTF(FF)) and serum (HTF(serum)). Embryo development was observed at $72 \mathrm{~h}$ and $96 \mathrm{~h}$ after incubation (Table 2). In the two modified HTF media, a greater percentage of the ICR mouse embryos cultured had developed to the morula stage after $72 \mathrm{~h}$ of culture than those cultured in HTF medium. At $96 \mathrm{~h}$ of incubation, the percentages of total blastocysts in $\operatorname{HTF}(\mathrm{FF})$ were also higher than those in HTF medium. In contrast, blastocyst formation was not increased in HTF(serum). CBFI mouse embryos developed well in all three 
Table 1. Amino acid concentrations (mean \pm SEM) in follicular fluid (FF), serum, Ham's F-10 and Eagle's MEM

\begin{tabular}{|c|c|c|c|c|}
\hline $\begin{array}{l}\text { Amino acids } \\
\left(\mu \mathrm{mol} l^{-I}\right)\end{array}$ & $\mathrm{FF}$ & Serum & Ham's F-10 & MEM \\
\hline \multicolumn{5}{|c|}{ Eagle's essential amino acids } \\
\hline Arg & $53.2 \pm 3.5^{\mathrm{a}}$ & $75.6 \pm 6.1$ & 1000 & 600 \\
\hline Cys-Cys & $5.6 \pm 1.2$ & $6.0 \pm 1.7$ & $*$ & 100 \\
\hline Gln & $178.8 \pm 8.5$ & $200.4 \pm 7.1$ & 1000 & 2000 \\
\hline His & $77.5 \pm 2.3^{\mathrm{a}}$ & $90.1 \pm 2.3$ & 100 & 200 \\
\hline Ile & $34.1 \pm 1.4^{\mathrm{a}}$ & $58.2 \pm 2.2$ & 20 & 400 \\
\hline Leu & $60.1 \pm 2.5^{\mathrm{a}}$ & $107.9 \pm 4.2$ & 100 & 400 \\
\hline Lys & $133.7 \pm 5.8^{\mathrm{a}}$ & $164.5 \pm 5.7$ & 160 & 400 \\
\hline Met & $14.3 \pm 0.8^{\mathrm{a}}$ & $21.0 \pm 0.6$ & 30 & 100 \\
\hline Phe & $41.7 \pm 1.3^{\mathrm{a}}$ & $56.1 \pm 2.6$ & 30 & 200 \\
\hline Thr & $124.0 \pm 6.2^{b}$ & $142.1 \pm 6.3$ & 30 & 400 \\
\hline $\operatorname{Trp}$ & $33.0 \pm 2.2$ & $38.5 \pm 2.5$ & 3 & 50 \\
\hline Tyr & $42.5 \pm 2.1$ & $48.0 \pm 2.4$ & 10 & 200 \\
\hline Val & $141.4 \pm 6.0$ & $186.6 \pm 7.4$ & 30 & 400 \\
\hline \multicolumn{5}{|c|}{ Eagle's non-essential amino acids } \\
\hline Ala & $298.8 \pm 17.2$ & $317.6 \pm 18.0$ & 100 & $*$ \\
\hline Asn & $64.8 \pm 8.9$ & $77.2 \pm 10.5$ & 100 & * \\
\hline Asp & $6.4 \pm 0.4^{\mathrm{a}}$ & $21.6 \pm 2.1$ & 100 & * \\
\hline Cys & ND & ND & 150 & * \\
\hline Glu & $92.6 \pm 4.7$ & $89.7 \pm 9.0$ & 100 & $*$ \\
\hline Gly & $154.3 \pm 11.2$ & $182.0 \pm 10.6$ & 100 & $*$ \\
\hline Pro & $101.4 \pm 4.3$ & $109.0 \pm 5.5$ & 100 & $*$ \\
\hline Ser & $73.8 \pm 4.1^{\mathrm{a}}$ & $126.6 \pm 5.5$ & 100 & $*$ \\
\hline Tau & $31.3 \pm 3.8^{\mathrm{a}}$ & $123.7 \pm 12.5$ & $*$ & * \\
\hline Total & $1763.4 \pm 95.2^{\mathrm{a}}$ & $2242.4 \pm 69.8$ & 3363 & 5450 \\
\hline
\end{tabular}

ND: not determined, *: not included.

${ }^{a, b}$ Significantly different from serum amino acids at $P<0.01, P<0.05$ respectively (non-paired Student's $t$ test). Arg: Arginine, Cys-Cys: Cystine, Gln: Glutamine, His: Histidine, Ile: Isoleucine, Leu: Leucine, Lys: Lysine, Met: Methionine, Phe: Phenylalanine, Thr: Threonine, Trp: Tryptophan, Tyr: Tyrosine, Val: Valine, Ala: Alanine, Asn: Asparagine, Asp: Asparatic acid, Cys: Cysteine, Glu: Glutamic acid, Gly: Glycine, Pro: Proline, Ser: Serine, Tau: Taurine.

media, and hatching blastocysts were observed after $96 \mathrm{~h}$ of incubation in $27.4 \%$ (HTF), $56.2 \%(\mathrm{HTF}(\mathrm{FF}))$ and $53.2 \%$ (HTF(serum)) of embryos.

The results of culturing ICR mouse embryos in HTF medium and three modified HTF media containing amino acids at concentrations found in follicular fluid (HTF(FF)), Ham's F-10 (HTF(F-10)) and MEM (HTF(MEM)) are shown (Table 3). The percentages of morulae at $72 \mathrm{~h}$ and blastocysts at $96 \mathrm{~h}$ in HTF(FF) were significantly higher than those in HTF medium and HTF(MEM). Use of HTF(F-10) and HTF(MEM) did not improve embryo development, and HTF(MEM) inhibited development to the expanded blastocyst stage at $96 \mathrm{~h}$ when compared with culture in $\operatorname{HTF}(\mathrm{FF})$.

The concentrations of ammonium in media during incubation are shown (Fig. 1a). Concentrations of ammonium in HTF were below $5 \mu \mathrm{g} \mathrm{ml}{ }^{-1}$ throughout the 3 days of incubation. Significantly higher concentrations of ammonium were detected in HTF(MEM) than in HTF at the start of the incubation. The concentration of ammonium in the media increased linearly with incubation time in the three media containing amino acids. High concentrations of ammonium (69.I and $34.2 \mu \mathrm{g} \mathrm{ml}^{-1}$ ) were observed in HTF(MEM) and HTF(F-10) media, respectively, after 3 days of incubation. However, the concentration of ammonium $\left(7.6 \mu \mathrm{g} \mathrm{ml}^{-1}\right)$ was low in $\operatorname{HTF}(\mathrm{FF})$ medium during the 3 days of incubation. Ammonium concentrations were similar when ten embryos were cultured in HTF $\left(2.9 \mu \mathrm{g} \mathrm{ml}^{-1}\right)$, HTF(FF) (10.1 $\left.\mu \mathrm{g} \mathrm{ml}^{-1}\right)$, $\operatorname{HTF}(M E M)\left(75.3 \mu \mathrm{g} \mathrm{ml}^{-1}\right)$ and $\operatorname{HTF}(\mathrm{F}-10)\left(38.4 \mu \mathrm{g} \mathrm{ml}^{-1}\right)$ media.

To determine the source of ammonium in the media, the breakdown of each amino acid in the culture media was measured. There was no significant reduction of the concentrations of the amino acids, with the exception of glutamine. The breakdown of glutamine during incubation is shown (Fig. $1 b)$. The reduction of glutamine concentrations paralleled the production of ammonium in each media. The reduction in glutamine concentration in $\operatorname{HTF}(\mathrm{FF})$ during incubation was minimal, when compared with that in HTF(MEM) or HTF(F-10), and the presence of embryos made no difference.

\section{Discussion}

Amino acids, vitamins and energy sources have been used to supplement culture media in an attempt to create optimal conditions for embryo development in vitro. Several reports have shown that supplementation with amino acids can enhance embryo development (Kane and Foote, 1970; Kane 
Table 2. Effects of amino acids present in follicular fluid (FF) and serum and added to human tubal fluid (HTF) medium on development of ICR and CBF1 one-cell mouse embryos

\begin{tabular}{|c|c|c|c|c|c|c|c|}
\hline \multirow[b]{2}{*}{ Medium } & \multirow[b]{2}{*}{$\begin{array}{c}\text { Number of } \\
\text { embryos }\end{array}$} & \multicolumn{6}{|c|}{ Percentage of one-cell embryos developing to } \\
\hline & & $<$ Morula & Morula & Blastocyst & $\begin{array}{l}\text { Expanded } \\
\text { blastocyst }\end{array}$ & $\begin{array}{l}\text { Hatching } \\
\text { blastocyst }\end{array}$ & $\begin{array}{c}\text { Total } \\
\text { blastocysts }\end{array}$ \\
\hline \multicolumn{8}{|c|}{ ICR mouse embryos after $72 \mathrm{~h}$ of culture } \\
\hline HTF & 81 & $54.4^{\mathrm{a}}$ & $45.6^{\mathrm{a}}$ & 0 & 0 & 0 & 0 \\
\hline $\mathrm{HTF}(\mathrm{FF})$ & 80 & $19.6^{\mathrm{b}}$ & $80.4^{b}$ & 0 & 0 & 0 & 0 \\
\hline HTF(serum) & 77 & $25.6^{\mathrm{b}}$ & $72.6^{\mathrm{b}}$ & 1.6 & 0 & 0 & 1.6 \\
\hline \multicolumn{8}{|c|}{ ICR mouse embryos after $96 \mathrm{~h}$ of culture } \\
\hline HTF & 81 & $54.4^{\mathrm{a}}$ & $18.2^{\mathrm{a}}$ & 7.0 & 20.2 & 0 & $27.4^{\mathrm{a}}$ \\
\hline $\mathrm{HTF}(\mathrm{FF})$ & 80 & $19.6^{\mathrm{b}}$ & $26.4^{a, b}$ & 9.0 & 39.0 & 6.2 & $53.8^{\mathrm{b}}$ \\
\hline HTF(serum) & 77 & $25.6^{\mathrm{b}}$ & $32.0^{b}$ & 10.0 & 26.2 & 6.2 & $42.2^{\mathrm{a}, \mathrm{b}}$ \\
\hline \multicolumn{8}{|c|}{ CBF1 mouse embryos after $72 \mathrm{~h}$ of culture } \\
\hline HTF & 67 & 13.2 & 72.8 & 14.0 & 0 & 0 & 14.0 \\
\hline $\operatorname{HTF}(\mathrm{FF})$ & 69 & 8.4 & 60.8 & 30.8 & 0 & 0 & 30.8 \\
\hline HTF(serum) & 68 & 12.0 & 63.4 & 25.0 & 0 & 0 & 25.0 \\
\hline \multicolumn{8}{|c|}{ CBFI mouse embryos after $96 \mathrm{~h}$ of culture } \\
\hline HTF & 67 & 13.2 & 0 & 9.0 & 50.6 & $27.4^{\mathrm{a}}$ & 87.0 \\
\hline $\mathrm{HTF}(\mathrm{FF})$ & 69 & 8.4 & 2.0 & 3.4 & 30.0 & $56.2^{b}$ & 89.6 \\
\hline HTF(serum) & 68 & 12.0 & 6.0 & 0 & 29.0 & $53.2^{a, b}$ & 82.0 \\
\hline
\end{tabular}

Values are expressed as mean \pm SEM. Values with different superscripts within each column are significantly different (ANOVA, Tukey, $P<0.05)$. Experiments were replicated five times.

Table 3. Effects of amino acids in three culture media on the development of ICR one-cell mouse embryos

\begin{tabular}{|c|c|c|c|c|c|c|c|}
\hline \multirow[b]{2}{*}{ Medium } & \multirow[b]{2}{*}{$\begin{array}{c}\text { Number of } \\
\text { embryos }\end{array}$} & \multicolumn{6}{|c|}{ Percentage of one-cell embryos developing to } \\
\hline & & $<$ Morula & Morula & Blastocyst & $\begin{array}{l}\text { Expanded } \\
\text { blastocyst }\end{array}$ & $\begin{array}{l}\text { Hatching } \\
\text { blastocyst }\end{array}$ & $\begin{array}{c}\text { Total } \\
\text { blastocysts }\end{array}$ \\
\hline \multicolumn{8}{|c|}{ Embryos after $72 \mathrm{~h}$ of culture } \\
\hline HTF & 78 & $50.3^{\mathrm{a}}$ & $49.7^{\mathrm{a}}$ & 0 & 0 & 0 & 0 \\
\hline $\mathrm{HTF}(\mathrm{FF})$ & 75 & $19.3^{\mathrm{b}}$ & $80.7^{\mathrm{b}}$ & 0 & 0 & 0 & 0 \\
\hline $\mathrm{HTF}(\mathrm{F}-\mathrm{IO})$ & 72 & $35.0^{a, b}$ & $65.0^{a, b}$ & 0 & 0 & 0 & 0 \\
\hline HTF(MEM) & 69 & $51.0^{a}$ & $49.0^{a}$ & 0 & 0 & 0 & 0 \\
\hline \multicolumn{8}{|c|}{ Embryos after $96 \mathrm{~h}$ of culture } \\
\hline HTF & 78 & $50.3^{\mathrm{a}}$ & 21.5 & 5.5 & $22.5^{\mathrm{a}}$ & 0 & $28.0^{\mathrm{a}}$ \\
\hline $\mathrm{HTF}(\mathrm{FF})$ & 75 & $19.3^{\mathrm{b}}$ & 20.0 & 0 & $47.3^{\mathrm{b}}$ & 13.3 & $60.5^{\mathrm{b}}$ \\
\hline $\mathrm{HTF}(\mathrm{F}-10)$ & 72 & $35.0^{\mathrm{a}, \mathrm{b}}$ & 23.0 & 13.3 & $26.5^{a, b}$ & 2.5 & $39.8^{a, b}$ \\
\hline HTF(MEM) & 69 & $51.0^{a}$ & 30.5 & 12.5 & $6.0^{\mathrm{a}}$ & 0 & $18.5^{\mathrm{a}}$ \\
\hline
\end{tabular}

et al., 1986; Miyoshi et al., 1995). However, the optimal concentration and composition of amino acids has remained unclear. To develop a medium for embryo culture in vitro, the concentrations of amino acids in serum and follicular fluid were measured. HTF medium is a common medium for human IVF and does not contain amino acids (Quinn et al., 1985). Therefore, HTF medium was used as a basic medium in this study. Two strains of mice, ICR and CBF1, were used to assess the effectiveness of supplementation of HTF with amino acids.

Culture with media supplemented with amino acids at concentrations present in serum and follicular fluid significantly stimulated morula formation in ICR mouse embryos after $72 \mathrm{~h}$ of incubation. Blastocyst formation after $96 \mathrm{~h}$ incubation was stimulated in HTF(FF), but not in HTF(serum). Development of mouse embryos is known to arrest at the two-cell stage (First and Barnes, 1989). In the present study, amino acids mainly facilitated development of early stages of embryos in ICR mice. Early mammalian embryogenesis has been reported to depend on the maternal messenger RNA pool and the transition from maternal to embryonic genome occurs at the two-cell stage in mice (Braude et al., 1979). Therefore, it is likely that amino acids are used as substrates in de novo protein synthesis in the early 

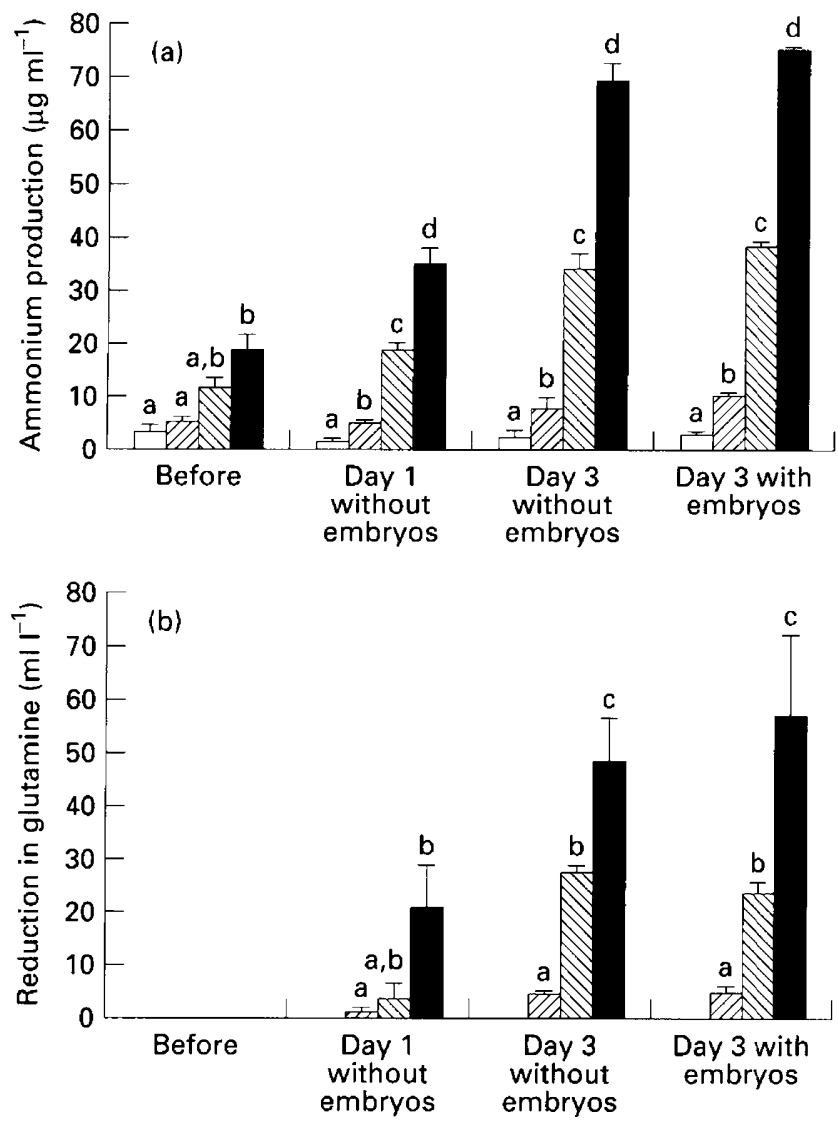

Fig. 1. (a) Production of ammonium and (b) reduction of glutamine concentration in each media during incubation at $37^{\circ} \mathrm{C}, 5 \% \mathrm{CO}_{2}$ in air with or without mouse embryos. Experiments were replicated three or five times. Values with different superscripts within each column were significantly different (ANOVA, Tukey, $P<0.05$ ). Each column represents the mean \pm SEM. Media: $\square$, HTF; $\square, \operatorname{HTF}(F F) ; \mathbb{H}, \operatorname{HTF}(F-10)$; a, HTF(MEM).

stage of development. Brinster (1971) reported that incorporation of amino acids into proteins is relatively low at the early preimplantation stage but increases in the later stages. Recent studies have suggested that amino acids are important not only for embryo development in vitro, but also for embryo viability and subsequent postimplantation fetal development (Mehta and Kiessling, 1990; Lane and Gardner, 1997). CBFI mouse embryos develop to the blastocyst stage without supplementation of the culture media with amino acid (Quinn, 1995), while the percentage of hatching blastocysts is improved by supplementation of amino acids at concentrations found in follicular fluid. In the present study, when CBFI mouse embryos were cultured for $120 \mathrm{~h}$ without amino acids, most blastocysts hatched (data not shown). These results suggest that amino acids at concentrations present in follicular fluid facilitate the development of CBFI mouse embryos. As with the ICR mice, HTF(FF) had a greater beneficial effect on the development of CBFI embryos than did HTF(serum). Therefore, $\mathrm{HTF}(\mathrm{FF})$ medium was used in subsequent experiments.

Ham's F-IO and MEM were developed as media for somatic cell culture and have been used in human IVF. However, supplementation of HTF with amino acids at concentrations used in these conventional media did not improve significantly development of ICR embryos, and the percentages of morulae at $72 \mathrm{~h}$ and of blastocysts at $96 \mathrm{~h}$ in HTF(MEM) were lower than those in $\mathrm{HTF}(\mathrm{FF})$.

The influence of individual supplementation of free amino acids on embryo development in vitro has been reported for several animal species. Bavister and Arlotto (1990) reported that the development of hamster embryos is stimulated by glycine, cysteine and lysine. Moore and Bondioli (1993) found that glycine and alanine enhanced the development of cattle embryos. The beneficial effect of glutamine has also been reported on the development of hamster (Carney and Bavister, 1987), cattle (Rieger et al., 1992), and mouse (Chatot et al., 1990) embryos. In contrast, the present study was designed to assess the effect of a mixture of amino acids at physiological concentrations on embryo development.

Previous studies have examined the effects of a mixture of amino acids on embryo development using commercially available supplements, refered to as Eagle's essential and non-essential amino acids. The addition of Eagle's non-essential amino acids to media is known to be beneficial for embryo development (Liu and Foote, 1995; Gardner and Lane, 1996). However, the present study found that Eagle's essential amino acids, which are identical to MEM-amino acids, are not beneficial for the development of mouse embryos (Gardner and Lane, 1993). Similar findings have been obtained for bovine (Liu and Foote, 1995) and hamster (Bavister and Arlotto, 1990) embryos. In contrast, the combination of non-essential amino acids with essential amino acids at the proportion used in the present study enhanced mouse embryo development, and the beneficial effects of amino acids at concentrations found in follicular fluid disappeared when essential amino acids were removed from HTF(FF) (data not shown). Lane and Gardner (1997) reported that development of mouse embryos and fetal development after transfer of blastocysts were improved by culture with essential amino acids at the eight-cell stage. Thus, the results presented here demonstrate that supplementation with total amino acids at appropriate concentrations is beneficial to embryo development.

Gardner and Lane (1993) reported that ammonium, an end-product of amino acid metabolism, increases in the culture medium during incubation, and is harmful to embryo development. In the present study, ammonium was produced, but the rate of production was significantly lower in $\mathrm{HTF}(\mathrm{FF})$ than in HTF(F-10) and HTF(MEM). Exposure of embryos to high concentrations of ammonium during culture induces fetal retardation and exencephaly (Lane and Gardner, 1994). However, the present results indicate that amino acids at concentrations present in follicular fluid can be safely used for embryo culture. The concentrations of total amino acids and glutamine in Ham's F-10 and MEM are higher than those found in follicular fluid. However, only the concentration of glutamine decreased during incubation in the absence or presence of embryos. Glutamine stimulates somatic cell growth and embryo development (Eagle, 1959; Bae and Foote, 1975; Carney and Bavister, 1987; Chatot et al., 1990; Rieger et al., 1992), but it is unstable in aqueous solution and breaks down spontaneously to ammonium when present at high concentrations (Fürst et al., 1990). Moreover, when amino acids were present at twice the concentration found in follicular fluid, the 
improvement of embryo development diminished (data not shown). These results indicate that embryo development in vitro is affected not only by the composition of amino acids in the culture media, but also by concentrations of amino acids, particularly glutamine.

In conclusion, amino acids at concentrations present in human follicular fluid promoted blastocyst formation of mouse embryos without high ammonium production. However, as embryo development in mice and humans is affected by other components, such as electrolyte, glucose concentration and osmolarity (Lawitts and Biggers, 1991; Baltz et al., 1991), additional research is needed to establish the optimum medium for human embryo development in vitro.

\section{References}

Bae IH and Foote RH (1975) Carbohydrate and amino acid requirements and ammonia production of rabbit follicular oocytes matured in vitro. Experimental Research 91 113-118

Baltz JM, Biggers JD and Lechene C (1991) Two-cell stage mouse embryos appear to lack mechanisms for alleviating intracellular acid loads journal of Biological Chemistry 266 6052-6057

Bavister BD and Arlotto T (1990) Influence of single amino acids on the development of hamster one-cell embryos in vitro. Molecular Reproduction and Development 25 45-51

Brinster RL (1971) Uptake and incorporation of amino acids by the preimplantation mouse embryo Journal of Reproduction and Fertility 27 329-338

Carney EW and Bavister BD (1987) Stimulatory and inhibitory effects of amino acids on the development of hamster eight-cell embryos in vitro. Journal of in vitro Fertilization and Embryo Transfer 4 162-167

Chatot CL, Tasca RJ and Ziomek CA (1990) Glutamine uptake and utilization by preimplantation mouse embryos in CZB medium journal of Reproduction and Fertility 89 335-346

Dandekar PV and Glass RH (1987) Development of mouse embryos in vitro is affected by strain and culture medium Gamete Research 17 279-285

Eagle H (1959) Amino acid metabolism in mammalian cell cultures Science 130 $432-437$

Epstein CJ and Smith SA (1973) Amino acid uptake and protein synthesis in preimplantation mouse embryos Developmental Biology 33 171-184

Eyestone WH and First NL (1989) Co-culture of early cattle embryos to the blastocyst stage with oviductal tissue or in conditioned medium journal of Reproduction and Ferfility $85715-720$

First NL and Barnes FL (1989) Development of preimplantation mammalian embryos. In Development of Preimplantation Embryos and their Environment pp 151-170 Eds K Yoshinaga and R Mori. Alan R. Liss Inc., New York

Fürst P, Albers S and Stehle P (1990) Glutamine-containing dipeptides in parenteral nutrition Journal of Parenteral and Enteral Nutrition 14 118-124

Gardner DK and Lane M (1993) Amino acids and ammonium regulate mouse embryo development in culture Biology of Reproduction 48 377-385

Gardner DK and Lane M (1996) Alleviation of the '2-cell block' and development to the blastocyst of CF1 mouse embryos: role of amino acids, EDTA and physical parameters Human Reproduction 11 2703-2712
Ham RG (1963) An improved nutrient solution for diploid Chinese hamster and human cell lines Experimental Cell Research 29 515-526

Kane MT and Foote RH (1970) Culture of two-and four-cell rabbit embryos to the expanding blastocyst stage in synthetic media Proceedings of the Society for Experimental Biology and Medicine $133921-925$

Kane MT, Carney EW and Bavister BD (1986) Vitamins and amino acids stimulate hamster blastocysts to hatch in vitro. Journal of Experimental Zoology $239429-432$

Kaye PL, Schultz GA, Johnson MH, Pratt HPM and Church RB (1982) Amino acid transport and exchange in preimplantation mouse embryos Journal of Reproduction and Fertility 65 367-380

Lamb VK and Leese HJ (1994) Uptake of a mixture of amino acids by mouse blastocysts Journal of Reproduction and Fertility 102 169-175

Lane M and Gardner DK (1994) Increase in postimplantation development of cultured mouse embryos by amino acids and induction of fetal retardation and exencephaly by ammonium ions Journal of Reproduction and Fertility $\mathbf{1 0 2}$ 305-312

Lane M and Gardner DK (1997) Differential regulation of mouse embryo development and viability by amino acids journal of Reproduction and Fertility 109 153-164

Lawitts JA and Biggers JD (1991) Overcoming the 2-cell block by modifying standard components in a mouse embryo culture medium Biology of Reproduction 45 245-251

Liu $\mathrm{Z}$ and Foote RH (1995) Effects of amino acids on the development of in vitro matured/in vitro fertilization bovine embryos in a simple protein-free medium Human Reproduction 10 2985-2991

Mehta TS and Kiessling (1990) Developmental potential of mouse embryos conceived in vitro and cultured in ethylenediaminetetraacetic acid with or without amino acids or serum Biology of Reproduction 43 600-606

Miyoshi K, Abeydeera LR, K Okuda and Niwa K (1995) Effects of osmolarity and amino acids in a chemically defined medium on development of rat one-cell embryos Journal of Reproduction and Fertility 103 27-32

Moore K and Bondioli KR (1993) Glycine and alanine supplementation of culture medium enhances development of in vitro matured and fertilized cattle embryos Biology of Reproduction 48 833-840

Morgan PM and Kane MT (1993) Protein content of rabbit embryos: one cell to pre-implantation blastocyst Journal of Reproduction and Fertility 97 101-106

Myers MW, Broussard JR, Menezo Y, Prough SG, Blackwell J, Godke RA and Thibodeaux JK (1994) Established cell lines and their conditioned media support bovine embryo development during in vitro culture Human Reproduction 9 1927-1931

Quinn P (1995) Enhanced results in mouse and human embryo culture using a modified human tubal fluid medium lacking glucose and phosphate Journal of Assisted Reproduction and Genetics 12 97-105

Quinn P, Kerin JF and Warnes GM (1985) Improved pregnancy rate in human in vitro fertilization with use of a medium based on the composition of human tubal fluid Fertility and Sterility 44 493-498

Rieger D, Loskutoff NM and Betteridge KJ (1992) Developmentally related changes in the metabolism of glucose and glutamine by cattle embryos produced and co-cultured in vilro. Journal of Reproduction and Fertility 95 $585-595$

Rorie RW, Lester TD, Miller GF, Gleidt DW and Mcnew RW (1994) Effect of protein source and co-culture on bovine embryo development in synthetic oviductal fluid medium Theriogenology 42 385-395 